\title{
Water-saving Concept and Technical Measures in High Rise Building Water Supply and Drainage System
}

\author{
Xuefeng Wang ${ }^{\mathrm{a}}$, Guizhen Hao ${ }^{\mathrm{b}}$ \\ School of Energy and Environmental Engineering, \\ Hebei Architectural and Civil Engineering Institute, \\ Hebei 075000, China; \\ E-mail: afalcon5680@163.com, bhaoguizhen8@163.com
}

\begin{abstract}
Along with the development of urbanization, the contradiction of Water resources shortage is increasingly prominent. The application of water-saving concept to the architectural design has been paid more and more attention. Water-saving concept can maximum saving water, protect environment and reduce pollution which distinguished from simple water conservation. This article is an analysis of the high rise building water supply and drainage of water saving direction which from the virtuous cycle of water resources point of view. The technical measures of water-saving on high rise building are focus on the development of unconventional water resources, sewage reuse, rainwater collection and usage, promote the use of water-saving appliances, green plot sprinkling and landscape water. Provide reference for the high rise building water supply and drainage project design.
\end{abstract}

Keywords-water-saving; high rise building; water resources; technical measures

\section{FOREWORD}

The traditional building industry is a great environmental pollution industry which needs huge quantities of natural resources and energy, cause soil erosion, vegetation degradation, reduction in the number of species and water pollution serious. With the environmental problems and the increasingly serious social problems, experts and scholars have put forward the concept of green building. The green building is the sustainable development of the construction, which in the whole building life cycle to maximize the conservation of resources (energy, land, water saving, material saving), protect environment and reduce pollution. Provide health, application and efficient use of space for humen people adn harmony with nature[1].

Water saving and water resources utilization is an important part of the green building, full life cycle throughout the construcion. To play a major role in taking effective water saving for protect environment and reduce the pollution. This paper is focus on the angel of the virtuous circle of water resources, analyzed the main measures, problems and suggestions in this field, point out the water saving direction on the high-rise building.

\section{ANALYSIS OF THE PLANNING DESIGN STAGE POINTS}

To correctly understand and use the green concept in the construction of water saving planning design, and the concept and technology really put into design is more important. This is put forward new requiements and challenges for the water supply and drainage engineers and environmental engineers.

\section{A. Design Points of Wter Saving and Water Resource Utilization}

In the green building water saving design always adopt the water saving rate to evaluat. The methods to improve the green building water saving rate include of water supply in different quality, the use of water saving appliances and equipment, avoid water supply pipe line loss, prevent the secondary pollution, green water saving irrigation and the use of reclaimed water[2].

The principle of water supply in different quality is high quality water on high level using, low quality on low level using. From the analysis of water resource sustainable utilization, the reclaimed water use is the best way of water ecosystey recyling. The use of reclaimed water technology including the recovery and utilization of rainwater and recycled water. The engeering design has to balance the advantage which combined with the natural conditions, economic capacity and demand for water. For the rainfall water shortage area, priority design rainwater collection, processing, storage and utilizing facilities. But for years of low rainfall area, construct large scale rainwater collection system is not suitable which will cause the facilities idle, wastewater reuse system is much better. The wastewater reuse system is to improve the water saving rate and the effective way of non traditional water resouce utilization. Design of building wastewater reuse system according to the different water quality adopt various treatment processes, which including physicochemical treatment, biological treatment and deep treatment technologies. Countries has mature experience adn examples in wastewater reuse which can reduce the sewage, to maximize the building water saving rate, made great contributions to reduce the burden for the urban water supply and drainage treatment system.

The use of water saving appliances and equipment is the most simple measures in construction of water saving. Will replace the traditional plumbing fixtrure such as lavatory pan, urinals and faucet like water saving type, the saving water is amazing. Especially the use of water saving toilet will greatly reduce the water in the propotion 
of residents living water and lower the utilization potential of recycling wastewater. It has been widely promote water saving devices were 3L/6L two stalls for water saving toilet, inflatable water tap, waterless urinals and low flow shower faucets.

In the design of greening irrigation, the non traditional water resource of recycled water and rainwater should be uesd for irrigation. Adopt spray irrigation is much better than wild flooding irrigation to save the flow of water $30 \%-50 \%$, the micro irrigation, infiltrating irrigation and low pressure irrigation also play an active role in beautify environment and improve air quality. The drought-enduring plant selection can reduce water flow to irrigate, even the annual rainfall can fulfil plant requirements.

Because of municipal water supply pipe line aging and corrosion, leakage caused by indoor plumbing fixtrure and water tank etc which make the huge waste of water resource. Promotion of new anti leakage technology, strengthen the leak detection work, use the industry standard pipe and fittings products, defining the outlet pressure and avoid continuous high pressure etc, to prevent the leakage of pipeline and eliminate the waste of water resource have a good effect.

\section{B. Rainwater Utilization and Control Urban Rainwater Runoff}

In the city construction and construction field, rainwater runoff lead to serious urban waterlogging and groundwater level decline. At the same time, large amounts of pollutants into the urban body with rainwater runoff which intensifiedd the urban water environment pollution.

Urban flood control and utilization research is always inseparable[3]. Different from the traditional gray infrastructure, scholars have put forward the concept of green infrastructure. It applied to the urban flood control and utilization by green infrastructure to reduce urban rainwater runoff and pollutants which can effectively solve the problem of urban flood. It can adopt the following ways according to residential area and park, such as green paking lot, can be used for the design and reconstruction of parking lot which is the combined application of permeability pavement, rain garden and low elevation greenbelt. Green street/road ,can be used for the design and reconstruction of community street and city road which is the combined application of permeability pavement, low elevation greenbelt and vegetation swales.

\section{PROBLEMS AND SUGGESTIONS}

Designers shoule establish the concept of green design, understanding the process and methods of green building water saving. The misunderstanding is that most people consider the green building is the use of a large number of advanced equipment and high cost, high tech architecture, makes the green building can not promote. The green design process should consider measures which consisten with national conditions, adopt low cost of ecological technology. The hall of Americal University of Florida Architectural Design Institute is a typical example. This hall rely on itself design archieve the aims for energy and water saving, while the voerall cost to control at a reasonable level. Sum up the main points of the water saving and water resource utization measures, as part of the road with permeable material laying, collection rainwater fo irrigation, the use of water saving appliances, besides drinking water other site must use recycling water and reducing the amount of water by selecting drought-enduring plant.

Different from traditional design, green building design has more emphasis on coordination between partial and whole, comprehensive consideration to establish a good relationship with other professional in the design process. It requires specialty departments to organize experts to train professional designers, to strengthen the assessment training work, improve the evaluation standard, formulate the excitation mechanism etc.

\section{ANALYSIS OF OPERATION MANAGEMENT STAGE}

In order to realize the harmony between architecture and environment, green building can not be confined to the stage of planning desige. To take the analysis method of whole life cycle, in operation management after the construction of delivery ensure the construction be controled and regulation.

Operation management of green building is mainly supported by modern science and technology, with corresponding property management personnel. It should be establish and implement water saving management system, development of waste management system, classified collection and disposal of waste, prevent secondary pollution. Regular inspection, cleaning and maintenace of equipment and pipeline to avoid the leakage losses. Focus on the research of green property management, achieve "people-construction-natural" three harmony.

\section{CONCLUSION}

Green building can maximize the conservation of resources and effectively resovle indoor environment and the effects of the external enivironment which is an important measure to cope with global climate change. As an important part of the green building, water saving and water resource utilization is an important embodiment of the connotation of green building. By control the state in construction planning design and operation management to improve the city residents living environment.

\section{CORRESPONDING AUTHOR}

Author: WANG Xuefeng (1980- ), lecturer, Master, special field is on research of the wastewater treatment and reusing for municipal sewage.

Email: falcon5680@163.com

Mobile phone: 15830399086 


\section{REFERENCES}

[1] GB/T 50378-2006, Green building evaluation criteria[S]

[2] WANG Ruo-zhu, MO Wei, QIAN Yong-mei. Application of Measures for Water Saving and Water Resources Utilization in Design of Green Buildings[J]. CHINA WATER \& WASTEWATER, 2009, 25(14): 22-24

[3] ZHANG Wei, CHE Wu, WANG Jian-long. Management of Urban Stormwater Runoff by Green infrastructures[J]. CHINA WATER \& WASTEWATER, 2011, 27(4): 22-27 